\title{
The use of Hajj fund for investment purpose: a maqashid sharia approach
}

\author{
Singgih Muheramtohadi ${ }^{1}$ \\ Universitas Islam Negeri Walisongo, Semarang, Indonesia
}

\begin{abstract}
Purpose - Hajj financial use The Haij is an obligation for Muslims who can carry out. Over time, the number of people who perform Hajj is increasing, but the quota is minimal. It raises new problems; one of them is the problem of the financial management of Hajj. The financial of Hajj accumulates and inflation occurs every year. One of the solutions to the financial problem in Haij is to invest in a productive field. The purpose of this paper is to find out the Islamic scholars' consideration of the justification of using Hajj fund and investing it in productive fields.
\end{abstract}

Method - This research is conducted through a qualitative descriptive approach.

Result - All Islamic organizations in Indonesia, especially MUI (Majelis Ulama Indonesia/ Indonesian Ulama Council), justify the Hajj financial use.

Implication - The result can be used by society as information and consideration regarding Haij and the mechanism of financial management in religious prayers administered by the government.

Originality - This research study the recent existence of investment purposes in Hajj fund management.

Keywords: consideration; Islamic scholar; Hajj; financial literacy;

maqashid

\footnotetext{
${ }^{1}$ Author correspondence: Singgih Muheramtohadi, singgih_muheramtohadi@walisongo.ac.id, Universitas Islam Negeri Walisongo, Jl. Walisongo No.3-5, Ngaliyan, Semarang, Indonesia
} 
Singgih Muheramtohadi

\section{Introduction}

The pilgrimage is the fifth pillar of Islam, and the law is obligatory for those who are able. The criteria of the 'capable,' according to Imam Shafi'i, are JIEMB | 120 physically, psychologically healthy and travel to the holy land and perform various pillars of Hajj. Thus, the tradition of making the pilgrimage to the holy land was carried out since the early development of Islam in the archipelago. With the formation of a government bureaucracy that governed population problems in the colonial era, the government also had an interest in regulating the departure to the holy land with the publication of the Hajj Ordinance for the first time in 1825 (Burhanudin, 2012). After the independence period, Hajj affairs came under the Department of Religion.

Hajj affairs are not only entirely religious. Because it has to be connected with government administration (providing visas and passports), financial relations (how much they will have to pay), and since 1976, the Saudi government has required a quota arrangement and departure of pilgrims from their respective countries. The purpose of this arrangement is the realization of a system administration so that all the needs for Hajj services can be met. (Nurhasanah, 2011)

Some time ago, there was a discourse about the use of Hajj Finance to support infrastructure development by the Government of Joko Widodo. The controversy arises, both pro and con, against the policy. However, most of the debate is political because the influence of political choices is very thick in determining attitudes.

Apart from the controversy surrounding the discourse, the problem of using Hajj to be used for public purposes is exciting to be studied more deeply. Because, on the one hand, there are financial deposits that are very abundant, but on the other hand, there is a deficit of the country's finances in financing development in the country. So, some parties suggested that using Hajj finance to finance infrastructure development (in the form of investment).

From the background above, this research answers several issues, namely the basis for the consideration of managing the financial pilgrimage for 
investment purposes, the rules of permissibility in Islamic jurisprudence, and the perspective of maqashid sharia upon the issue.

\section{Methods}

This study uses a qualitative descriptive approach. This type of research is JIEMB | 121 descriptive and does not go through statistical procedures or other forms of calculation (Sugiarto, 2015). This type of research is library research. Literature research is a type of research based on library sources, whether in the form of books, scientific journals, legislation products, documents, and so on. Literature research also can be defined as research that uses library research to obtain data (Zed, 2008).

Several types of library sources used in this study consisted of sources, such as Regulation Number 34 of 2014 concerning Hajj Financial Management, the books of usul figh, various documentation from the fatwa, bahtsul masail and ijtima' of the scholars.

This study uses two methods, namely description, and analysis. After the data is obtained, the data must be arranged in words in written form to produce a detailed picture of an object (description) (Siyoto and Sidik, 2015). The second method is, various information that comes through these sources must also be analyzed, taking into account every detail or its constituent elements, as well as examining the relationships between the structures (analysis) (Inwanto, 2006).

\section{Result and discussions}

\section{The foundation of Hajj fund management policy}

The condition of Indonesia, which has not fluctuated since the 1998 crisis, has caused Indonesia's economic growth to exceed more than $5 \%$ per year, which indicates more significant economic activity from year to year (Frisdiantara and Mukhlis, 2016). Along with economic stability, the number of Hajj registrations has increased from year to year, causing longer waiting lists. The number of Hajj registrations from year to year shows an increase, on the 
other hand, the Indonesian Hajj quota 'only' of 221,000 Hajj pilgrims (Jordan, 2017). While on the financial management of the pilgrimage, it led to the deposition of accounts in the Ministry of Religion. According to the Head of the Hajj Public Relations Bureau, Mastuki, as reported by the BBC, that his party had invested pilgrimage finance in several instruments such as Sharia Deposits and SBSN (State Sharia Securities) since the issuance of Law Number 13 of 2008.

Data from the Ministry of Religion shows that BPIH (Hajj Administration Agency) manages 97.18 Trillion in 2017 (Primadhyta, 2017). It can be imagined, if the number of Hajj registrants per year is 500 thousand, and the initial deposit is 25 million, then the amount of money that goes into the account of the Ministry of Religion is around 5.5 trillion. While the waiting list numbers showed an increase. Thus, it is natural that the government makes tightening on the Hajj registration, as well as easing the Hajj administration system.

The problem of settling the 'pilgrimage fund' is not new, the emergence of Law Number 34 of 2014 concerning Hajj Financial Management (Regulation of PKH), as well as the establishment of the Implementing Agency of the Act, called the BPKH (Hajj Financial Management Agency) at the end Susilo Bambang Yudhoyono (Indonesia's sixth president) government.

BPKH is a body of five implementing members appointed and dismissed by the president at one time (for five years), one chair and four members, with the chairman Dr. Anggito Abhimanyu. The main objectives of establishing BPKH are (BPKH 2018):

1. Improve the quality of the organization of the Hajj

2. Increase the rationality and efficiency of the use of the cost of Hajj.

3. Increase the benefits for the benefit of the Islamic ummah. (Regulation No. 34 of 2014 concerning PKH)

The purpose of the establishment of the BPKH is in line with the criticism that has been made during the pilgrimage in Indonesia by several parties, including: 
1. Criticism of the low level of Hajj satisfaction, due to the lack of quality of services provided by Hajj organizers. (Mustami, 2017)

2. Criticism of the possibility of inflation of Hajj financing, or waste. So that number should be reduced to a minimum. (Rastika, 2014)

3. criticism of the low aspect of the benefits of the (ample) pilgrimage funds against the benefit of the Islamic ummah. On one side, the number of pilgrims increased, but on the other hand, the poverty rate of Muslims did not decrease.

Based on the above considerations, BPKH members are not selected from the ulama figures. Whereas scholars of fiqh, act as supervisory bodies, such as KH Marsudi Suhud (PBNU).

Hajj Financial Management through BPKH for investment purposes is not a new step, previously, Malaysia since 1962 has established Tabung Haji (Hajj Saving). The field of Hajj activities covers various things, such as property, hotels, oil palm plantations, trade, and so on. When the monetary crisis hit the region of Southeast Asian countries, Tabung Haji helped bail out several businesses that were threatened with bankruptcy in Malaysia. Thus, Tabung Haji becomes the world's largest sharia-based non-bank financial institution. With total assets of 180 Trillion, with investments in property totaling 24 Trillion, in the fields of Plantation, concessions and equipment totaling 11 Trillion, Foreign investments totaling 17.8 Trillion and Deposits of 19.8 Trillion (Firman, 2017).

This success in developing Hajj funds has had an impact on improving Hajj services, such as providing Hajj guidance 15 times in 6 months and having the ability to rent comfortable lodgings close to the Grand Mosque, as well as several other forms of Hajj services that are on par with the ONH Standard (Sudrajat 2017). Although the success of the Tabung Haji inspired BPKH, both have different principles.

1. Hajj registration in Indonesia through the Ministry of Religion, while in Malaysia through the Lembaga Tabung Haji/LTH (Board of Hajj Savings). 
Singgih Muheramtohadi

Both are different, Kemenag is a government department, while LTH is a state-owned enterprise.

2. $\mathrm{BPKH}$ is a body that functions to regulate and plan financial management and is non-profit. Whereas the Tabung Haji, as conducted in Malaysia, are based on profit-oriented, and run as with other business entities.

3. The benefits obtained by the Tabung Haji are direct and higher (i.e., 20$30 \%$ per year), while the benefits from Indonesian Hajj fund are not direct (because through the Indonesian Haj Sukuk Fund / SDHI) which projections of minimal profits (i.e., 8- 12\%) (Word, 2017).

\section{The rationale for using Hajj fund for investment}

Islamic Economics is a science that discusses human behavior in carrying out economic activities under sharia law '. Hajj, although a part of mahdhah worship, the journey to the holy sites of Mecca requires travel, consumption and accommodation costs, which involve financial matters.

The state regulates the hajj fund, so it involves elements of the government bureaucracy, in this case, the religious department and the finance department. Financial management of Moslems who want to go on pilgrimage to the government in the form of wadi'ah (goods for safekeeping), and according to sharia review, wadi'ah is a safekeeping item that must be safeguarded and must be returned at any time if the customer wants. Wadi'ah is divided into two types, namely wadiah yad al amanah, and wadiah yad dhomanah (Shomad, 2010). The position of the use of the Hajj fund in Islamic economics is a wadi'ah yad dhomanah item, in which the party entrusted (in this case, the department Religion and Finance) has the right to use these funds.

Financial management of the pilgrimage is done by investing in several sectors. Including placement in Unit Usaha Sharia (Sharia Business Units) \& Badan Usaha Sharia (Sharia Business Entity) is possible. Investment is a commitment to some funds, with the aim of obtaining profits in the future 
(Faniyah, 2017). In the Islamic economy itself, investment is divided into several forms such as Syariah or mudharabah.

In the book of Minhajul Muslim, the so-called sharia are two or more people who have the assets they collect to make investments in trade, industry or agriculture (Al Jazzairi, 2015) while mudharabah is a contract (contract) between the owner of funds (shohibul maal) and operators who run businesses (mudharib) (Amrin, 2009) whereas ushul fiqh, in this case, is to examine more deeply how the istinbath process of the scholars in allowing the use of Hajj funds.

According to Amisyah Tambunan in the Mimbar Ulama magazine: The 42Year Journey of the Indonesian Ulema Council (MUI) (Tambunan, 2017), states that the steps for the use of Hajj funds should be adjusted to the Law on Hajj Financial Management in Indonesia. So the author researches how the Law on Hajj Financial Management with ushul fiqh and how its effects.

\section{The fatwa of Indonesian Ulama upon the use of Hajj fund}

Almost all scholars agree on the use of Hajj funds for other purposes, based on the principle of maslahah wa mursalah. Several ulama institutions have issued fatwas about the legal status of the use of financial pilgrimage, including:

\section{MUI (Indonesian Ulema Council)}

The fatwa on the use of Hajj funds was issued by the Indonesian Ulema Council (MUI) which held the ljtima 'Ulama Forum for Fatwa Commission in Indonesia IV in Cipasung in 2012, which resulted in several fatwas, including the ability to translate the financial of the Hajj pilgrims on the list of pilgrims. Waiting for productive matters, whether placed in Islamic banking or the form of Sukuk (Khoiron, 2017). The results of the placement of the money belonging to prospective pilgrims.

The same thing was said by Asrorun as Secretary of the MUI Fatwa Commission in the discussion on "Infrastructure Investment from Hajj Funds" 
Singgih Muheramtohadi

in the DPR / MPR Building, by providing several requirements, which include (MUI: Hajj Funds Can Be Used for Investment by 2017 Fatwa):

1) Hajj funds may be invested in types of businesses that meet sharia principles.

2) Hajj funds should not be reduced after being invested, so the placement of Hajj funds must pay attention to investment security.

3) Investments from the pilgrimage fund must pay attention to aspects of benefits aimed at the pilgrims or for the benefit of the Muslims.

4) The use of Hajj funds must pay attention to the principle of Liquidity or the company's ability to meet obligations that are due in due course. In this case, there must be a guarantee that the user does not disrupt the continuation of the pilgrimage whose funds amount to 3.5 Trillion spent each Hajj season arrives.

Majelis Mujahidin Indonesia (MMI)

Indonesian Mujahidin Majlis, headquartered in Kotagede, Yogyakarta, on August 3, 2017, issued a letter containing "Statement of the Mujahideen Council on the Use of Hajj Funds by the Government," containing several core statements, that Investment from Hajj fund must be following sharia principles, prudence, and the value of benefits, and must be run for the benefit of pilgrims and the benefit of Muslims. Furthermore, avoid even the slightest use that comes in contact with unlawful and good, including government projects that are loaded with political interests.

\section{Nahdatul Ulama}

Responding to Jokowi's government policy in the use of Hajj fund for infrastructure, the PBNU conducted several discussions, one of which was the National Conference (Munas) Alim Ulama who carried out Bahtsul Masail on November 24, 2017, to discuss the legal position of the use of haj funds. (Alhafiz, 2017)

In the session, several things were produced, one of which was that the use of Hajj funds for infrastructure was permissible, but investments had to be 
placed in the most beneficial and safe areas, and provided clear benefits. The resulting profits belong to prospective pilgrims. If there is a loss, then it must be the responsibility of BPKH and the government.

\section{PP Muhammadiyah}

Muhammadiyah, as it has not officially issued a fatwa related to the use of Haij funds for the benefit of the Ummah. However, according to the Chairperson of the Economy and Entrepreneurship Division of PP Muhammadiyah, Anwar Abbas, as reported by Republika, stated that the placement of Hajj funds in the SBSN (National Sharia Certificate) has not yet yielded optimal benefits, the funds could have been utilized for the benefit of the wider community. Meanwhile, according to the Chairman of the Muhammadiyah Youth PP, Dahnil Anzar Simanjuntak, said that if the pilgrimage funds are used for other purposes (outside the affairs of the pilgrimage), then it should require a contract from the beginning, and investment in sectors that have shallow risk, and according to him placement in the infrastructure sector has a high enough risk. Also, according to him, the Hajj Fund is a restricted fund, so its use must be for the benefit of Hajj (Syakur, 2017).

All these ulama institutions state their ability to use the Hajj funds and all state that the use of these funds must be per sharia, transparent (open), using the precautionary principle in choosing the investment field, and the value of its benefits, especially in prospective pilgrims and on benefit of Muslims as a whole.

Management of Hajj funds by the government, both used for the needs of Hajj services and used as SBSN (State Sharia Securities), is separate ijtihad. Because this problem is not regulated through texts, even in the provisions of the Imams of the schools, however, some scholars developed the Usul rules which could be used as a basis for conducting ijtihad. For example, the rules of ushul about mashlahah wa mursahalah and the methods of maqashid asy shariah as developed by Syatibi. In subsequent developments in modern times, along with efforts to answer the demands of the times, the Islamic 
Singgih Muheramtohadi

economy develops. because Muslims need legal certainty related to economic activities they do. Assessing the use of Haj funds through an economic perspective is essential. Finding out the basis for sharia law and its position in the Islamic economy.

\section{The use of Hajj fund for investment according to maqashid sharia}

Hajj fund is all types of wealth that can be valued in money (both in the form of money or goods), which comes from the rights and obligations of the government related to the implementation of the pilgrimage, both from pilgrims or other legal and non-binding sources. (Regulation Number 34 the Year 2014 Regarding Hajj Financial Management Article 1)

The government must provide administrative services, guidance, accommodation, transportation and Hajj services (Arifin, 2010), the costs of which come from pilgrims provided to the government through the accounts of the Ministry of Religion. While the source of Hajj fund, apart from prospective pilgrims' deposits, also comes from the remaining pilgrimage operational funds called the DAU (Dana Abadi Umat), which in its management uses a waqf model. (Arifin, 2010)

Hajj fund, in terms of legislation, is distinguished from the Hajj Fund. Hajj fund includes all Hajj funds, from the money generated from the pilgrimage deposit, the remainder of the pilgrimage and the Endowment Fund. Whereas the Hajj Fund is another term for the Dana Abadi Umat. Thus, the Endowment Fund is counted as 'endowment.'

Indonesian scholars in justifying the use of Hajj fund for investment purposes commonly use the term maslahah. Maslahat comes from Arabic namely صلاح which means improvement. Meanwhile, according to al Ghazali maslahah is an effort to bring benefits and resist danger. The nature of ijtihad itself is to reject mafsadah, while taking aspects of benefit. However, rejecting mafsadah (damage) must take precedence over taking advantage. From the above thought, the ushul figh rules develop, namely:

Avoiding mafsadah is preferred than taking advantage. 
Consideration to prevent disputes can be seen from the MUI argument when allowing the use of Hajj funds. As reported by CNN Indonesia, quoting the opinion of Asrorun, the MUI Fatwa Commission, stated that "when the pilgrimage costs deposited reached 25 million per prospective pilgrims, so that funds collected reach trillion per year, whether the funds should be allowed to stand and shrink because a steady rate of inflation, or is it productive? " (Ferry, 2017)

Judging from the arguments above, what is done by the MUI is trying to avoid the nature of mafsadah, namely the accumulation of assets that is continuous and deposited, and will decrease in value continuously because inflation is averagely inflation per year of around $6 \%$. So, if not utilized productively, it will lose $6 \%$ per year from the amount of Hajj funds, which amount to hundreds of trillions.

The measurement in determining ijtihad is also based on the objectives of Islamic Sharia, known as maqashid asy shari'ah (Sholihin, 2010). So that benefit is not only seen in terms of material (hifzh al maal) but on other aspects, namely on religion (hifzh al din) and maintaining common sense (hifzh al aql).

From the shari'a maqashid, the following things are obtained:

1. On the issue of hifzh maal (protecting property).

As explained earlier, the use of Hajj funds, as a form of protecting the assets of prospective pilgrims from the decline in value, because it is kept (deposited) during the waiting period of the implementation of the pilgrimage. If a person makes a pilgrimage this year at 35 million, and he will leave for the pilgrimage in 20 years, and inflation at $6 \%$ per year, one can imagine the value of the money he had set aside during this period.

2. On the issue of hifzh al aqli (protecting the common sense)

In figh, usually hifzh al aqli is associated with the prohibition of consuming alcoholic drinks. Because the effects of these drinks will disturb the mind, and cause a decrease in the function of the mind. According to contemporary scholars, the function of reason has to do with science. In Islam itself, hifzh al Aqli is also done by means of ijtihad. One of the most important ijtihad 
Singgih Muheramtohadi

products is the preservation of the Qur'an with the Koran's Mushaf AlKoodification policy during the Caliph Uthman ibn Affan. If the Muslim community survives with its old-fashioned attitude, by allowing the Qur'ans to be scattered everywhere without any standard that is owned, then various Qur'ans may emerge with very different versions.

Hajj financial management is one solution to the problem because the income from Hajj funds managed by the state (through the Ministry of Religion, then diverted to $\mathrm{BPKH}$ ) is higher than the expenditure, so there will be a continuous buildup. This problem is obvious in front of the eye, and there needs to be a breakthrough step (ijtihad) to overcome this problem.

3. On the issue of hifzh al dïn (oversee the faith/religion)

The function of the utilization of financial pilgrimage can also be seen from efforts to maintain the religion of Islam. In the maqashid of sharia, hifzh al-din, guarding the religion of Islam, so that hifzh al diin is often associated with the Shari'a command to conduct jihad and da'wah. With jihad, Islam can be defended from attacks or aggression from other parties. While with da'wah, the values of Islam can be instilled in the midst of society. One element of da'wah is religious symbols.

As is known, funds collected and managed by state agencies amount to hundreds of trillions of rupiah. This money is entirely the property of Muslims. It can be imagined the number of funds collected and its potential if used for positive things, especially in the field of state development.

\section{The harmony of maqashid sharia in the use of Hajj fund under the purpose of Islamic Economic}

Islamic Economics is the study of human economic behavior based on Islamic Shariah rules. while the objectives of Islamic Economics are (Suryani and Hendryadi, 2016):

1. Falah achievement, or glory, is not only in the world but also in the hereafter. So that Islamic economic activity, is not only directed to the interests of the world, but also the hereafter. This goal as mentioned in QS 
Al Baqarah verse 201 and al Qashash verse 77. The use of Hajj funds, if managed professionally, can improve the economic welfare of millions of Muslims, who are below the poverty line, to avoid the threat of apostasy. Both in the form of employment, empowerment/capital, and through philanthropic activities (zakat and shodaqoh). So here, the attainment of glory (al falaah) does not only include hifzh al maal, but hifzh al dit.

2. Realize an equitable and equitable distribution of the economy. As mentioned in QS Al Hasyr: 7. Either manifested in the form of government policies, or manifested in daily ethics. In Islam, people who do not care about others are people who denounce the religion of Surah Al Ma'un 13. The use of Hajj funds that are not managed, there will be a buildup, and only revolve in state institutions without perceived aspects of its benefits for the people. Thus, the use of Hajj fund is not only aimed at profitoriented, but must be based on the goal of helping to realize economic equality. So here the objectives of the Shari'a (maqashid shari'ah) are fulfilled, in terms of safeguarding property (hifzh al maal) and safeguarding of common sense, because of the value of property is not wasted uselessly and avoiding wasteful behavior (hifzh al aql).

3. Availability of meeting basic needs, both in the form of clothing, shelter, and food for the entire population. As stated in QS Al Hud paragraph 6. Basic needs in the form of food, shelter and clothing, are types of basic needs, where the state must provide guarantees to meet these needs. Hajj funds (in the form of waqf) are the remnants of the pilgrimage, worth hundreds of trillions if managed effectively, can create affordable housing for the poor. Meeting the needs of a decent life is part of hifzh an nafs (protecting the soul).

4. Uphold social and economic justice. "Justice" is a word that is mentioned repeatedly in the Qur'an, as in QS An Nisa 'verse 58, QS An Nisa' 135, Al Maidah verse 8, Al An'am 152, and other verses which if counted reach hundreds of verses that contain meaning about the importance of upholding al 'is (justice). Hajj fund in the value of hundreds of trillions is a substantial value, if managed professionally and effectively, will be able to 
Singgih Muheramtohadi

compete with established private financial institutions, where it becomes the economic power of the Islamic ummah (which is generally economically marginalized), to compete in the economic field. so that here occurs the function of hifzh al aql (maintaining common sense) which ultimately impacts on the preservation of property (hifzh al maal).

5. Prioritizing love and brotherhood to fellow Muslims. Zakat and Hajj are a form of ukhuwah islamiyyah. As can be seen in QS Al Hujurat verse 10 and Al Hijr verses 45-47. Hajj Financial Management must be based on the principle of togetherness united by ukhuwah islamiyyah. Thus, the investment goal of millions of Muslims is not intended to pursue personal benefits through the investment he planted but also intended as a solution to improve the welfare of fellow Muslims. Here is the function of hifzh al in (maintaining religion) in the management of financial pilgrimage.

\section{Conclusion}

Almost all Indonesian Ulema agreed to use the pilgrimage funds for investment purposes, including the Indonesian Mujahidin Council. Denial of use is generally based on the principle of prudence in investment. The rejection is not a substantive rejection, but a rejection of a technical nature. The Ulama's consideration, if seen from the various statements it issued, was based on one rule of ushul figh, namely maslahah wa mursalah. In Islamic figh, maslahah wa mursalah, must be in accordance with maqashid sharia.

In this study, the author found several things that are suitable with the type of maqashid sharia, namely the use of Hajj fund can be used as one of the Islamic symbols in the field of economic productivity (hifzh ad diin), the use of Haij fund is a form of ijtihad based on knowledge and reason healthy (hifzh al $a q l$ ), so that the Islamic ummah can avoid being closed and conservative. Other functions of the use of financial pilgrimage, as maintaining assets that are entrusted so as not to shrink its value caused by inflation (hifzh al maal).

The use of Hajj fund, if done professionally, is also consistent with the objectives of Islamic economic scholarship. A knowledge that not only serves 
The use of Hajj fund as investment...

to 'just knowing', but more than that, has a goal in empowering Muslims, strengthening in the economic field, and the realization of equity.

\section{References}

Alhafiz (2017) Ini Sikap NU Terkait Polemik Investasi Dana Haji Untuk Proyek Infrastruktur. $\quad$ http://www.nu.or.id/post/read/83661/ini-sikap-nuterkait-polemik-investasi-dana-haji-untuk-proyek-infrastruktur.

Al Jazzairi, Abu Bakar Jabir (2015) Minhajul Muslim, Terj. Ferdian Hasmand ,. Al Kautsar.

Amrin, Abdullah (2009) Bisnis, Ekonomi, Asuransi, \& Keuangan Syariah, Jakarta: Grassindo,.

Arifin, Gus (2010) Tip\&Trik Ibadah Haji \& Umrah. Jakarta: Gramedia,.

BPKH (2018) Diseminasi Peran Pengawasan Keuangan Haji. In . bpkh.go.id/.

Burhanudin, Jajat (2012) Ulama Dan Kekuasaan: Pergumulan Elite Politik Muslim Dalam Sejarah Indonesia,. Bandung: Mizan,.

Faniyah, lyah (2017), Investasi Syariah Dalam Pembangunan Ekonomi Indonesia,. Sleman: Depublish,.

Ferry, Oscar (2017) MUI Fatwakan 4 Syarat Pemanfaatan Dana Haji. https://www.cnnindonesia.com/nasional/20170802100639-20231857/mui-fatwakan-4-syarat-pemanfaatan-dana-haji.

Firman, Muhammad (2017), Beda Cara Kelola Dana Haji Indonesia vs Malaysia. https://katadata.co.id/infografik/2017/08/03/beda-carakelola-dana-haji-indonesia-vs-malaysia.

Frisdiantara, Christea, and Imam Mukhlis, (2016) Ekonomi Pembangunan: Sebuah Kajian Teoretis Dan Empiris,. Malang: Lembaga Penerbitan Universitas Kanjuruhan.

Irwanto (2006) Focused Group Discussion: Sebuah Pengantar Praktis,. Jakarta: Yayasan Obor.

Jordan, Ray (2017) Presiden Jokowi: Kuota Haji Indonesia Untuk 2017 Jadi 221 Ribu. https://news.detik.com/berita/3393547/presiden-jokowi-kuota- 
Singgih Muheramtohadi

haji-indonesia-untuk-2017-jadi-221-ribu (diakses pada tanggal 30 Agustus 2018).

Khoiron(2017) Soal Investasi Dana Haji, MUI Kuatkan Pandangan Menteri Agama. https://kemenag.go.id/berita/read/505062/soal-investasidana-haji----mui-kuatkan-pandangan-menteri-agama.

MMI (2017) Pernyataan Majelis Mujahidin Penggunaan Dana Haji Oleh Pemerintah. https://www.majelismujahidin.com/pernyataan-majelismujahidin-penggunaan-dana-haji-oleh-pemerintah/.

Mustami, Adinda Ade (2017) Kepuasan Jemaah Di Arafah Dan Mina Turun. http://fokus.kontan.co.id/news/kepuasan-jemaah-di-arafahdan-mina-turun.

Nurhasanah (2011), Hajj saving Malaysia Dalam Perspektif Ekonomi,. Allqtishad: , Vol. III.

Primadhyta, Safyra (2017) Untung Dan Buntung Investasi Dana Haji Ke Infrastruktur.

https://www.cnnindonesia.com/ekonomi/20170802121306-78-

231888/untung-dan-buntung-investasi-dana-haji-ke-infrastruktur.

Rastika, Icha (2014) KPK Duga Ada Penggelembungan Harga Dalam Proyek Haji.

https://nasional.kompas.com/read/2014/05/22/2321543/KPK.Duga.Ad a.Penggelembungan.Harga.dalam.Proyek.Haji.

Shidiq, Saifudin (2017) Ushul Fiqh,. Jakarta: Kencana, 2017),.

Sholihin, Ahmad Ifham (2010) Buku Pintar Ekonomi Syariah,. Jakarta: Gramedia.

Shomad, Abd. (2010) Hukum Islam: Penormaan Prinsip Syariah Dalam Hukum Indonesia Ed. Revisi,. Jakarta: Kencana,.

Siyoto, Sandu, and M. Ali Sidik (2015), Dasar Metodologi Penelitian,. Sleman: Literasi Publishing.

Sudrajat (2017) 10 Tabungan Haji Malaysia. https://finance.detik.com/infografis/d-3577028/begini-pengelolaandana-haji-di-malaysia.

Sugiarto, Eko (2015) Menyusun Proposal Penelitian Kualitatif: Skripsi Dan Tesis,. Yogyakarta: Suaka Media. 
Suryani, and Hendryadi, (2016) Metode Riset Kuantitatif: Teori Dan Aplikasi Pada Bidang Penelitian Manajemen Dan Ekonomi Islam,. Jakarta: Kencana,

Syakur, Muhammad Abdus (2017) Soal Penggunaan Dana Umat, Dahnil: Sebaiknya Pemerintah Fokus Perbaikan Pelayanan Haji. https://www.hidayatullah.com/berita/info-hajiumrah/read/2017/07/30/120667/soal-penggunaan-dana-umatdahnil-sebaiknya-pemerintah-fokus-perbaikan-pelayanan-haji.html.

Tambunan, Amisyah (2017) Optimalisasi Pengelolaan Dana Haji,: Mimbar Ulama: Suara Majelis Ulama Indonesia.

Undang-Undang Nomor 34 Tahun 2014 Tentang Pengelolaan Keuangan Haji N.d.

Zed, Mustika (2008) Metode Penelitian Kepustakaan, Hlm. 1. Jakarta: Yayasan Obor 
Singgih Muheramtohadi

JIEMB | 136

Journal of Islamic Economics, Management, and Business - Vol. 1 No. 1 (2019) 